\title{
Occupational therapy for patients with an arterio-venous fistula
}

\author{
Iustinian BENGULESCU ${ }^{1}$, Costin PASNICU ${ }^{2}$, Corina PANTEA ${ }^{3}$, Stelian PANTEA ${ }^{4}$
}

\begin{abstract}
End stage renal disease (ESRD) represents a chronic medical condition that has become a public health problem and requires substantial funding. The number of patients with ESRD is rapidly increasing. From the moment that ESRD is diagnosed, the natural evolution of this pathology is towards mandatory dialysis, in absence of a renal transplant procedure. In order to perform hemodialysis, a vascular access site must be created and maintained functional. A proper vascular access site allows an adequate blood flow through the dialysis machine, in order to obtain the required results. The arterio-venous fistula represents the number one recommended vascular access site procedure. Establishing and maintaining a vascular access represents one of the biggest problems in hemodialysis. The arterio-venous fistula thus becomes the patient's lifeline. Maintaining a good quality vascular access site is a demanding process and requires cooperation between both the patient and the health care providers. For ESRD patients there is a constant concern regarding the patency of their vascular access. The aim of this paper is to present the postoperative measures that ESRD patients should provide in order to preserve their vascular access. Also, we want to present the main signs of an early complication that patients should recognize and therefore immediately present themselves to the physician. By establishing this type of cooperation and trust between the patient and the medical staff we will be able to reduce the number of surgical procedures required for the creation and maintenance of the vascular access. Our final thought remains that a well-informed patient has better chances of prolonging his "lifeline".
\end{abstract}

Keywords: ESRD, hemodialysis, vascular access maintenance, arterio-venous fistula

\section{Rezumat}

Boala renală în stadiu final (BRSF) reprezintă o problemă de sănătate publică, cu un important impact în mediul economic. Numărul pacienților cu BRSF este într-o continuă creștere. Din momentul diagnosticului, evoluția bolii, în absența transplantului renal, este spre dependență de dializă. Pentru a se putea realiza ședințele de hemodializă este necesară crearea unui abord vascular și păstrarea functionalității acestuia. Un abord vascular funcțional asigură un debit sanguin corespunzător aparatului de dializă, pentru a obține rezultatele dorite. Fistula arterio-venoasă reprezintă prima alegere în realizarea abordului vascular. Realizarea și menținerea patentei fistulei arterio-venoase reprezintă unul din cele mai dificile capitole ale hemodializei. Astfel, fistula arterio-venoasă devine "linia vieții" pentru pacienți. Menținerea functionalității abordului vascular în cele mai bune condiții reprezintă o provocare atât pentru pacient cât și pentru personalul medical, fiind necesară o foarte bună colaborare între cele două părți. Pentru pacienții cu BRSF, funcționalitatea abordului vascular devine o preocupare constantă. Scopul acestei lucrări este de a prezenta principalele măsuri pe care pacienții trebuie să le asigure postoperator pentru a menține funcționalitatea abordului vascular, de asemenea vom prezenta și principalele semne pe care pacienții trebuie să le recunoască, pentru a putea diagnostica din timp eventualele complicații, asigurând astfel o bună șansă în tratarea acestora prin prezentarea din timp la spital. Printr-o astfel de relație de încredere și cooperare între pacient și echipajul medical vom reuși să scădem numărul de proceduri chirurgicale necesare menținerii funcționării la standarde optime a abordului vascular. Gândul nostru final este acela că un pacient bine informat are șanse mai bune de a-și prelungi această "linie a vieții".

Cuvinte cheie: BRSF, hemodializă, menținerea abordului vascular, fistula arterio-venoasă

\footnotetext{
${ }^{1}$ Surgery resident physician, $2^{\text {nd }}$ Surgery Clinic, Timisoara Emergency County Hospital no 1, Timisoara, Romania, corresponding author e-mail address: iusti19@yahoo.com

2Surgery resident physician, Surgical Department, Nephrology Hospital "Carol Davila", Bucharest, Romania

${ }^{3}$ Assoc. Professor PhD, West University of Timișoara, Faculty of Physical Education and Sports, Romania

${ }^{4}$ Lect. PhD, Departament of General Surgery, University of Medicine and Pharmacy "V. Babeș" Timișoara, Romania
}

Volume 8 Issue $15 \diamond 2015$ 


\section{Introduction}

End stage renal disease (ESRD) represents a chronic medical condition that has become a public health problem and requires substantial funding. The number of patients with ESRD is rapidly increasing due to an increase in the number of patients with associated comorbidities that lead to kidney failure. Diabetes mellitus represents the most significant disease from this group [1].Other pathology is represented by: atherosclerosis, hypertension and systemic inflammatory disease. From the moment that ESRD is diagnosed, the natural evolution of this pathology is towards mandatory dialysis, in absence of a renal transplant procedure. Due to the liberalization of the dialysis acceptance criteria (and especially hemodialysis), the number of patients that can have this procedure performed has risen along with the patients age [2,3]. Patients with ESRD that require hemodialysis need to undergo 3 hemodialysis sessions weekly. In order to perform hemodialysis, a vascular access site must be created and maintained functional. During hemodialysis blood is pumped from the patient's vessels through the dialysis machine and returned into the patient's venous system cleaned of toxins in a similar way as your normal functioning kidneys would do it.

\section{Vascular access}

A proper vascular access site allows an adequate blood flow through the dialysis machine, in order to obtain the required results. Therefore the surgeon has to create a link between the patient's arterial system and his venous system, ensuring that the blood entering the dialysis machine satisfies the needed flow, and that the blood is then returned into the patient's venous system. The vascular access can be performed either through a catheter or through an arterio-venous fistula. Dialysis catheters can be cuffed permanent catheters or emergency catheters. Hemodialysis cannot be performed for a longer duration through the catheter due to an increased rate of associated complications (thrombosis, stenosis, infection)[4,5]. The arterio-venous fistula remains the only long term feasible solution, but raises numerous difficulties in the surgical management.[6]. A vast majority of these patients has a compromised vascular capital, due to the numerous venipunctures performed throughout their life. These venipunctures unfortunately are needed for their regular follow ups. Also, the patient's comorbidities take part in the diminution of the vascular capital, especially diabetes mellitus through its vascular complications. All the highly variable parameters diminish the vascular capital addressability (especially the venous capital)for an arterio-venous fistula, thus leading to an increase in the number of surgical procedures needed for establishing a functional fistula, but also diminishing its patency. All of the above have a significant impact on the patient's life expectancy. Current literature data suggests a number of 1,2 procedures/patient/year necessary for maintaining the fistula's patency $[7,8]$. The arterio-venous fistula represents the recommended first vascular access site procedure [9]. Establishing and maintaining a vascular access represents one of the biggest problems in hemodialysis [10] with almost $20 \%$ of hospital admissions for clients on dialysis being for vascular access complications [11]. The arteriovenous fistula thus becomes the patient's lifeline and the patients should be given specialized advice on how to properly take care of their fistula, and also to recognize the main signs of an early complication and therefore immediately present themselves to the physician

\section{Taking care of the arterio-venous fistula}

After the arterio-venous fistula is created and if no complications have been detected, the following day, the patients are discharged. Before leaving the hospital all patients are given a detailed briefing on how to properly take care of their fistula. All this information will also be provided in the discharge papers.

Postoperative the patients should keep the area dry and clean, and if swelling, bleeding, discharge or severe pain is present they should report to the hospital.

Daily routine: The patient's daily routine, besides some limitations, should not be affected. Patients should use caution when handling sharp objects; also the patients should not wear restrictive or tight fitting clothing that could apply pressure on the upper limb that has the fistula; watches, and bracelets should be worn on the other hand. The patients are also advised not to lean or sleep on the arm with the fistula.

We advise all our patients to inform any medical staff not to measure blood pressure on the arm with the fistula and not to take blood samples from this arm.

Daily checklist: All patients are informed that after the fistula is created, a buzzing sensation known as the "thrill" should be felt along the venous component of the fistula. Patients are required to check for the "thrill" daily, even after they started hemodialysis, and if any modifications occur 
(absence or a diminished thrill) they should present to the hospital. Besides checking for the thrill, a daily checkup of the upper limb should be performed. Patients are informed to check the distal pulse and to check for swelling, redness or any tenderness. If the fistula becomes swollen, painful or blue the patients should report to the hospital. All these measures help increase the fistula's patency by recognizing any complications that might develop and treating them at the optimum moment, as shown by literature data $[12,13]$. The most common complications that a fistula could develop are shown in table I.

Exercising: Regular movement in the upper limb should not be limited; furthermore patients are encouraged in performing daily physical activity in order to help maintain their fistula. However certain limitations apply. In table II we present these limitations along with the permitted physical activity. All these are applied to the upper limb were the fistula was created.

All our patients are informed about this self-care measures that they need to apply, an because this is a continuous learning experience for the patients, the medical staff is always prepared to answer any questions that the patients may ask, underlining again that at the slightest modification in the thrill, the immediate perception of any of the symptoms shown in table 1or at any time that the patients feel any alteration in their health status they should present to the hospital immediately and have a specialist examine them.

Maintaining the proper functioning of the fistula represents a team effort in which the patient plays a key role.

Table I. Arterio-venous fistula most common complications

\begin{tabular}{lll}
\hline Complication & Symptoms & Recommended therapy \\
\hline Clotting & $\begin{array}{l}\text { Absence/diminished -thrill } \\
\text { Tenderness }\end{array}$ & $\begin{array}{l}\text { Interventional therapy } \\
\text { surgery }\end{array}$ \\
\hline Steal syndrome & $\begin{array}{l}\text { Pain } \\
\text { Cold hand }\end{array}$ & Surgical evaluation +therapy \\
\hline Arm/forearm edema & $\begin{array}{l}\text { Swelling } \\
\text { Pain }\end{array}$ & $\begin{array}{l}\text { Use a raised position for your arm while in bed } \\
\text { Surgical evaluation }\end{array}$ \\
\hline Neuropathy & Tingling sensation in the hand & Surgical evaluation \\
\hline Aneurism & Pouch like swelling over the fistula & Surgical treatment \\
& vessel, usually at the puncture site & \\
\hline Infection & $\begin{array}{l}\text { Redness, pain } \\
\text { Discharge }\end{array}$ & $\begin{array}{l}\text { Antibiotics } \\
\text { Surgical evaluation }\end{array}$ \\
\hline Bleeding & Severe hemorrhage & $\begin{array}{l}\text { Immediately apply pressure at the site of the } \\
\text { bleeding and phone the ambulance. }\end{array}$ \\
\hline
\end{tabular}

Table II. Arterio-venous fistula recommended physical activity and limitations

\begin{tabular}{lll}
\hline Permitted & Not permitted & Recommended \\
\hline $\begin{array}{l}\text { Regular activities: washing, eating, } \\
\text { clothing, use of regular household } \\
\text { equipment (coffee filter, computer, }\end{array}$ & $\begin{array}{l}\text { Handling power tools, gardening, } \\
\text { lifting heavy objects, carrying heavy } \\
\text { objects, smart phone, stove etc.) }\end{array}$ & $\begin{array}{l}\text { Daily hand exercises: squeezing a } \\
\text { rubber ball for 5 minutes, performed 3 } \\
\text { Restrictions: sleeping and leaning on } \\
\text { the arm with the vascular access }\end{array}$ \\
\hline
\end{tabular}

\section{Recommendations for patients with arterio- venous fistula}

Regular physical activity as well as physical exercises, which include the upper limb, should not be limited. However muscle strengthening exercises for the upper limb should be carried out with small weights in order not to put pressure on the fistula, which could lead to complications. Therefore we recommend aqua gym once a week. This is a physical aquatic training that consists in a warm up, a main part and at the end a part of stretching and relaxing. The main part is a specialized form of gymnastics using foam tubes, foam dumbbells, foam balls and swimming raft. It strengthens muscle 
groups and increases endurance [14]. Besides aqua gym we recommend jogging or walking at least thirty minutes as a daily routine. It is very important that the physical activity involves the entire body. Therefore cycling should be also an option. Depending on the possibilities it can be carried out outdoors on a classic bicycle or on a stationary bicycle. Anyhow the indications are fifteen-thirty minutes two times a week. Another possibility would be cycling exercises performed in the supine position two series of ten minutes a day. Recommendations of physical activities for the upper body are: flexion and extension exercises of the forearm using dumbbells; flexion and extension of the hand and fingers using rubber rings and rubber balls; extensions of the arm with stretching the elastic band; compression of the foam ball between the palms. All the exercises should be carried out bilateral and with dumbbells not heavier than one $\mathrm{kg}$. The indication is two series of ten repeats, two times a day for each type of exercise. However, for the exercise using the rubber rings and rubber band the series should be doubled

By respecting these recommendations the patient will be able to develop and maintain fistula for o longer period of time. Last but not least it increases the muscle strength and endurance.

\section{Conclusion}

Maintaining a good quality vascular access site is a demanding process and requires cooperation between both the patient and the health care providers. For ESRD patients there is a constant concern regarding the patency of their vascular access, and sometimes even in their relations with the medical staff. The patients may feel the need to overprotect their vascular access. We encourage this type of behavior and acknowledge that the patient is more aware of his body and hope that all patients will develop a state of self-awareness in such manner that even the slightest, perhaps medically irrelevant, modification, will determine the patient to address the physician. Only if we establish this type of cooperation and trust between the patient and the medical staff we will be able to reduce, in the future, the number of surgical procedures required for the creation and maintenance of the vascular access. Our final thought remains that a well-informed patient has better chances of prolonging his "lifeline".
"This paper was co-financed from the European Social Fund through Sectoral Operational Programme - Human Resources Development 20072013", project number POSDRU/1871.5/S/155605, entitled "Scientific excelence, knowledge and innovation through doctoral programs in priority areas", Beneficiary - University of Petrosani.

\section{References}

1. Tordoir J., Canaud B., Haage P., Konner K., Basci A., Fouque D et al. (2007) EBPG on vascular access. Nephrology Dialysis Transplantation, 22: ii88-ii117;

2. Saran R., Pisoni R.L., Weitzel W.F. (2004) Epidemiology of vascular access for hemodialysis and related practice patterns. Contributions to Nephrology, 142:14-28;

3. DeOreo B.P. (1997) Hemodialysis patient-assessed functional health status predicts continued survival, hospitalization and dialysis-attendance compliance. Am J Kidney Disease, 30:204-212;

4. Ware J.E., Sherbourne C.D. (1992) TheMOS 36-item shortform health survey (SF-36).Med Care; 30:473-483;

5. Cagney K.A., Wu A.W, Fink N.E. et al (2000) Formal literature review of quality of life instruments used in end stage renal disease.Am J Kidney Dis, 36:327-336;

6. Rettig R.A., Sadler J.H.,Meyer K.B. et al. (1997)Assessing health and quality of life outcomes in dialysis:a report on an Institute of Medicine workshop. Am J Kidney Dis, 30:140155;

7. Martin-McDonald K., Biernoff D. (2002) Initiation into a dialysis dependent life:An examination of rites of passage. Nephrology Nursing Journal, 29: 347-352;

8. Harris L.E., Luft F.C., Rudy D.W. et al. (1993) Clinical correlates of functional status in patients with chronic renal insufficiency. Am J Kidney Dis, 21:161-166;

9. Rebollo P., Ortega F., Baltar J.M. et al. (1998) Health-related quality of life (HRQOL) in end stage renal disease (ESRD) patients over 65 years. GeriatrNephrolUrol, 8:85-94;

10. Wasse H., Kutner N., Zhang R.and Huang Y.(2007) Association of initial hemodialysis vascular access with patient reported health status and quality of life.Clin J Am SocNephrol, 2(4):708-714;

11. Richard C.J., Engebretson J. (2010) Negotiating life with an arterio-venous fistula for hemodialysis .Nephrology Nursing Journal, 37(4):363-375;

12. Blake C., Plant W.D. (2003) Measures to improve quality of life in end stage renal disease patients. In:Brady H.D. and Wilcox C.S. (eds).Therapy in Nephrology and Hypertension, Saunders, Philadelphia, 747-751;

13. Seica A., Segall L., Verzan C., Vaduva N., Madincea M., Rusoiu S. et al. (2009) Factors affecting the quality of life of hemodialysis patients from Romania: a multicenter study. Nephrol Dial Transplant, 24:626-629.

14. Dziubek W., Bulinska K., Rogowski L. Golebiowskiet T. al. (2015) The effects of aquatic exercises on physical fitness and muscle function in dialysis patients. BioMed Research International, 912980 